\title{
IMPLEMENTASI TEKNOLOGI VIRTUAL TOUR PERPUSTAKAAN MENGGUNAKAN METODE PENGEMBANGAN MULTIMEDIA DEVELOPMENT LIFE CYCLE (MDLC)
}

\author{
Agis Maulana $^{1}$, Vidila Rosalina ${ }^{2}$, Eva Safaah $^{3}$ \\ 1,2,3 Jurusan Teknik Informatika Fakultas Teknologi Informasi Universitas Serang Raya \\ Jln. Raya Cilegon Serang - Drangong Kota Serang \\ ²vidila.suhendarsah@gmail.com
}

\begin{abstract}
Abstrak - Perpustakaan Saija Adinda merupakan perpustakaan umum yang diresmikan dan dibuka pada tanggal 27 Desember 2017. Kegiatan pengenalan perpustakaan Saija Adinda saat ini dengan cara penyampaian informasi secara tertulis melalui media online atau media cetak yang berada di wilayah Banten, sehingga tidak semua masyarakat mengetahui Perpustakaan Saija Adinda. Pengenalan menggunakan teknologi Virtual Tour 3 dimensi ini diharapkan dapat meningkatkan minat masyarakat Kabupaten Lebak untuk mengunjungi perpustakaan Saija Adinda dan memudahkan masyarakat dalam menemukan tata letak ruangan serta penempatan koleksi buku di perpustakaan Saija Adinda. Pengembangan aplikasi virtual tour ini menggunakan metode pengembangan multimedia versi Luther yang terdiri dari enam tahapan yaitu Concept, Design, Material Collection, Assembly, testing, Distribution, dan dibangun menggunakan software Adobe Audition, blender 3D, Unity 2018 1.6f1, dan notepad ++. Hasil akhir sebuah aplikasi pengenalan Perpustakaan Saija Adinda adalah aplikasi berbasis android yang dapat di unggah di play store, sehingga dapat diunduh dan digunakan pengunjung perpustakaan Saija Adinda.
\end{abstract}

Kata Kunci : Android, Lebak, Luther, Perpustakaan Adinda Saija, Virtual Tour.

\section{Pendahuluan}

Seiring dengan perkembangan teknologi yang semakin berkembang, berbagai macam teknologi telah diciptakan untuk berbagai keperluan dan pada berbagai bidang ilmu. Terutama dalam bidang informasi, edukasi dan komunikasi, adapun dengan perkembangan ini dapat menimbulkan banyak dampak positif bagi para pemakai atau user. Kebutuhan informasi dalam media pengenalan masih banyak menggunakan cara konvensional dan tidak memadukan unsur - unsur teknologi modern, salah satu bentuk penyampaian informasi atau pengenalan suatu gedung yang dapat digunakan adalah dengan menggunakan teknologi Virtual $\operatorname{Tour}(V R)$ [1].

Mengingat tingkat literasi masyakat Banten yang masih rendah perpustakaan memiliki peranan yang sangat penting dalam meningkatkan budaya literasi di Banten. Menurut peraturan Undang-Undang Republik Indonesia Nomor 43
Tahun 2007 tentang Perpustakaan bahwa "budaya kegemaran membaca dilakukan melalui keluarga, satuan pendidikan, dan masyarakat dengan kerjasama antara pemerintah dalam upaya peningkatan minat baca, dimana pemerintah bertindak sebagai penanggungjawab utama dan pustakawan melakukan kinerja yang optimal" [2].

Perpustakaan umum Saija Adinda terletak di alun-alun kabupaten Lebak Banten diresmikan pada tanggal 27 Desember 2017 terdiri dari tiga lantai bangunan yang cukup luas. Guna untuk menarik minat masyarakat dan mempromosikan keberadaan perpustakaan Saija Adinda ini maka dibuatlah teknologi Virtual Tour yang memvisualisasikan keadaan tata letak ruang perpustakaan dan penempatan buku-buku di perpustakaan.

Kegiatan pengenalan Perpustakaan Saija Adinda saat ini dengan cara penyampaian informasi secara tertulis melalui media online atau media cetak yang berada di wilayah Banten, sehingga tidak semua masyarakat mengetahui keberadaan 
perpustakaan Saija Adinda, dengan pengenalan menggunakan teknologi Virtual Tour 3 dimensi masyarakat Kabupaten Lebak dapat mengetahui letak persisnya Perpustakaan Saija Adinda sehingga diharapkan dapat menarik minat masyarakat untuk mengunjungi Perpustakaan Saija Adinda dan mempermudah dalam pencarian koleksi buku di perpustakaan Adinda Saija.

Virtual Tour merupakan Teknologi yang menempatkan user untuk menganalisa daya lihat secara signifikan. Virtual tour merupakan sebuah simulasi dari sebuah lokasi yang terdiri dari rentetan. Rentetan gambar tersebut akan digabungkan (stitch) untuk menghasilkan foto panorama $360^{\circ}$. Virtual tour sendiri biasanya digunakan untuk memberi pengalaman 'pernah berada' di suatu tempat hanya dengan melihat layar monitor. Penyajian virtual tour dapat dilakukan dengan cara memanfaatkan gambar ataupun video, selain itu dapat menggunakan model 3 dimensi [3] [4].

Tujuan dari penelitian ini yaitu merancang dan membangun suatu aplikasi berbasis virtual tour menggunakan metode Luther yang dapat digunakan masyarakat Kabupaten Lebak untuk mengetahui tata ruang perpustakaan Saija Adinda di Kabupaten Lebak dan mempermudah dalam menemukan koleksi buku-buku di perpustakaan Adinda Saija.

\section{Metodologi Penelitian}

Metode yang digunakan adalah metode pengembangan perangkat lunak multimedia versi Luther. Metode ini dikembangkan oleh Luther (1994) menurut Luther [5]

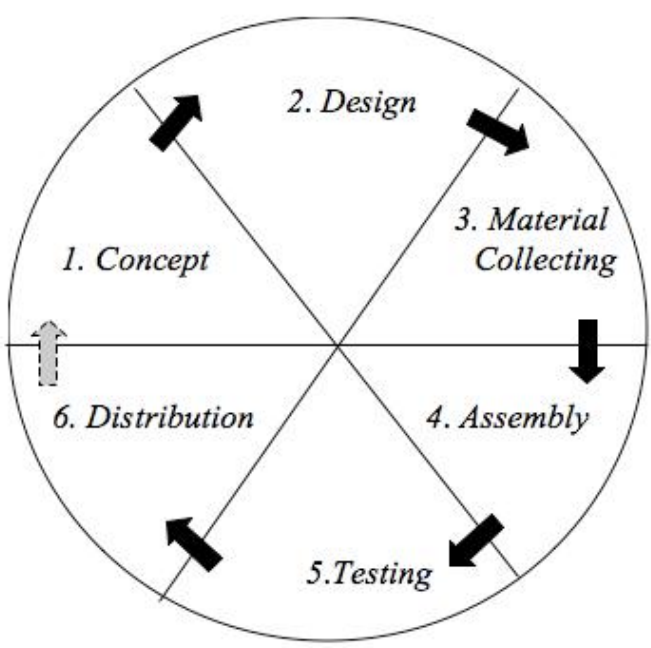

Gambar 1. Diagram Metodelogi Penelitian

\section{A.Konsep (Concept)}

Tahapan awal dari tahapan pengembangan multimedia ini adalah merancang konsep.
Setelah merancang konsep, kemudian dapat dirancang isi mengenai apa yang akan disampaikan. Rancangan yang akan dimasukan ke dalam informasi yang disampaikan harus sesuai dengan konsep yang disusun . Desain yang dibuat akan di isi dengan beberapa media diantaranya, teks, audio, animasi , gambar, dan objek 3D yang akan ditempatkan ke dalam beberapa menu baik di menu utama maupun di menu lainnya.

\section{C.Pengumpulan Bahan (Material Collecting)}

Tahap di mana pengumpulan bahan yang sesuai dengan kebutuhan dilakukan. Tahap ini dapat dikerjakan parallel dengan tahap Assembly. Pada beberapa kasus, tahap material collecting dan tahap Assembly akan dikerjakan secara linear tidak parallel

\section{D.Pembuatan (Assembly)}

Adalah tahap dimana semua objek atau bahan multimedia dibuat. Pembuatan aplikasi didasarkan pada tahap design.

\section{E.Pengujian (Testing)}

Dilakukan setelah selesai tahap pembuatan (assembly) dengan menjalankan aplikasi atau program dan dilihat apakah ada kesalahan atau tidak. Tahap ini disebut juga sebagai tahap pengujian alpha (alpha test) di mana pengujian dilakukan oleh pembuat atau di lingkungan pembuatannya sendiri.

\section{F.Distribusi (Distribution)}

Distribusi adalah tahap akhir dari penelitian ini, yang dimana aplikasi yang telah dibuat didistribusikan kepada user.

\section{HASIL DAN PEMBAHASAN}

\section{A. Konsep (Concept)}

Tahapan awal adalah merancang konsep. Pada perancangan konsep aplikasi pengenalan perpustakaan Adinda Saija ini diantaranya adalah mengidentifikasi audiens sasaran dan strategi yang akan diterapkan pada penelitian sehingga kemudian dibuatlah konsep yang sesuai dengan perpustakaan Adinda Saija, Lebak, Banten, Indonesia.

\section{B. Perancangan (Design)}

Setelah merancang konsep, kemudian merancang isi mengenai apa yang akan disampaikan di aplikasi ini. Rancangan isi yang di masukan ke dalam informasi yang disampaikan harus sesuai dengan konsep yang disusun serta tidak menyimpang dari tujuan dibuatnya aplikasi pengenalan Perpustakaan Saija Adinda ini.

\section{1) Perancangan Struktur Navigasi}

\section{B.Perancangan (Design)}


Struktur navigasi adalah struktur atau alur dari suatu program dan dapat membantu mengorganisasikan seluruh elemen pembukaan program aplikasi. Struktur navigasi yang digunakan penulis adalah struktur navigasi campuran/ komposit.

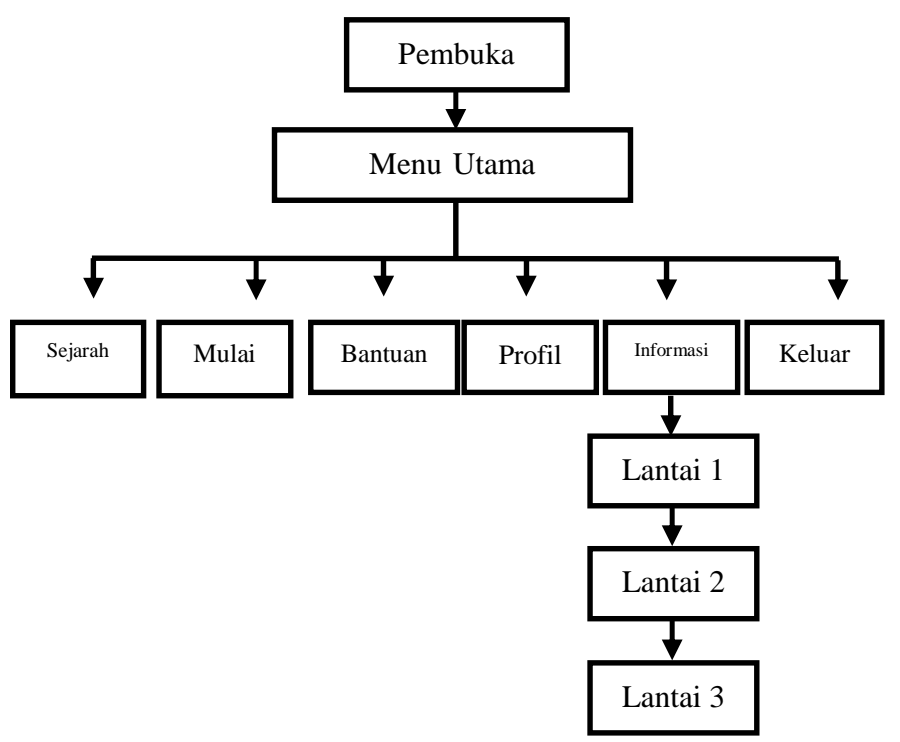

Gambar 2. Struktur Navigasi VR Perpustakaan Saija Adinda

\section{Pengumpulan Bahan (Material Collecting)}

Sesuai dengan desain yang telah dirancang, maka dapat ditemukan beberapa komponen yang akan dibutuhkan dalam tahap pembuatan media ini, dan berikut adalah komponen yang telah didapat.

\section{Pembuatan (Assembly)}

Pembuatan aplikasi ini dibangun menggunakan software Adobe Audition, blender 3D, Unity 2018 1.6f1, dan notepad ++. [6] [7] didasarkan pada tahap dari design dan pembuatan model bangunan 3 dimensi Perpustakaan Saija Adinda. Dalam pembuatan Perpustakaan Saija Adinda ini dilakukan beberapa tahap, yaitu proses Editing, proses Modelling, Proses Pembuatan Tampilan dan Fungsi, Finishing dan Deskripsi Hasil. Masing-masing tahap akan dijelaskan sebagai berikut :

\section{1).Modelling}

Modelling dilakukan sebagai dasar pembuatan dalam aplikasi, untuk membuat objek 3D bagunan Perpustakaan Saija Adinda dengan software Blender 3D .

\section{2). Editing}

Proses editing gambar dikerjakan dengan software Adobe Photoshop CC 2015, pada tahap ini menggabungkan beberapa gambar menjadi sebuah tombol.

\section{3). Tampilan dan Fungsi}

Pembuatan tampilan dikerjakan dengan software Unity $3 \mathrm{~d}$, pada tahapan ini akan dijelaskan sebagai berikut :

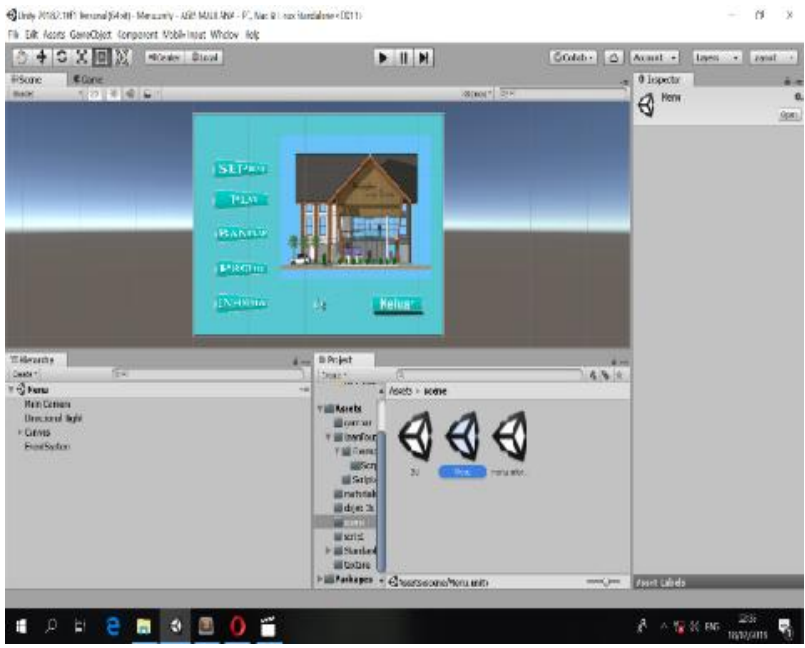

Gambar 3. Tampilan Pembuatan Menu Utama

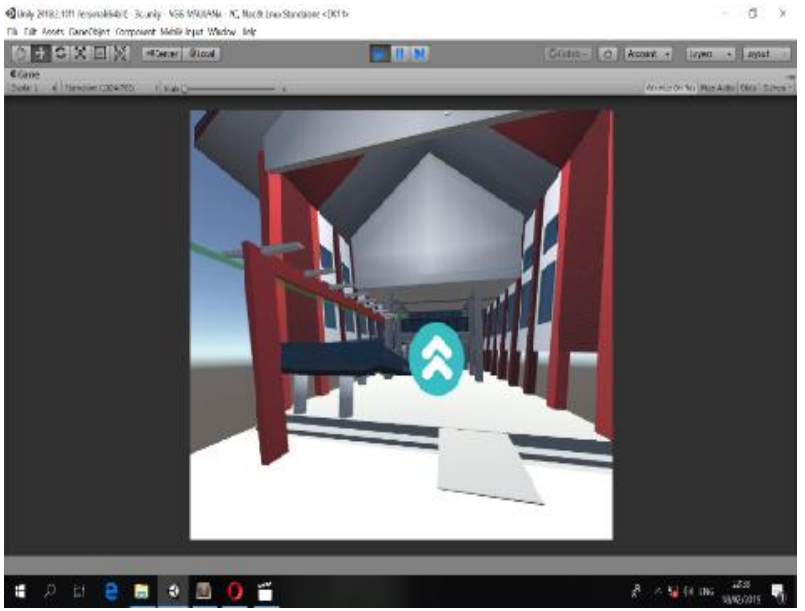

Gambar 4. Tampilan Pembuatan Menu Play Lantai 1 


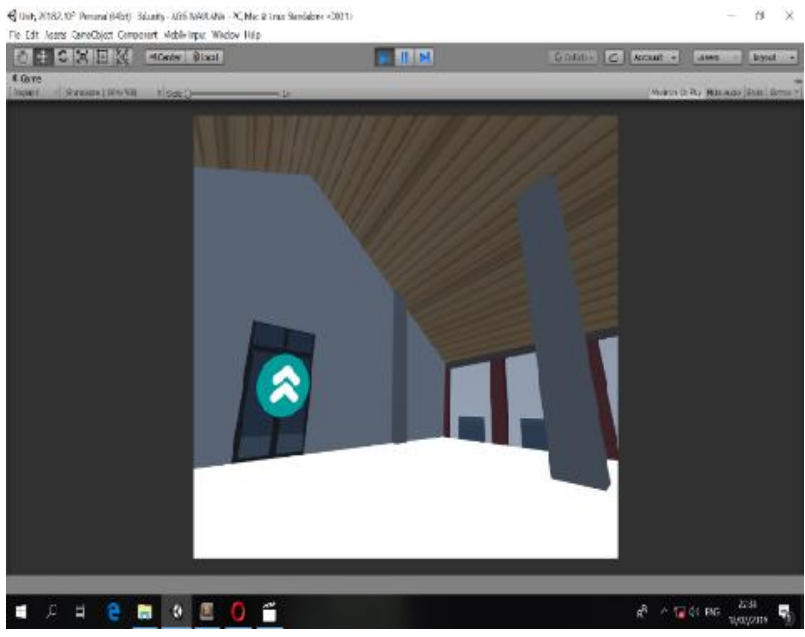

Gambar 5. Tampilan Pembuatan Menu Play Lantai Dua

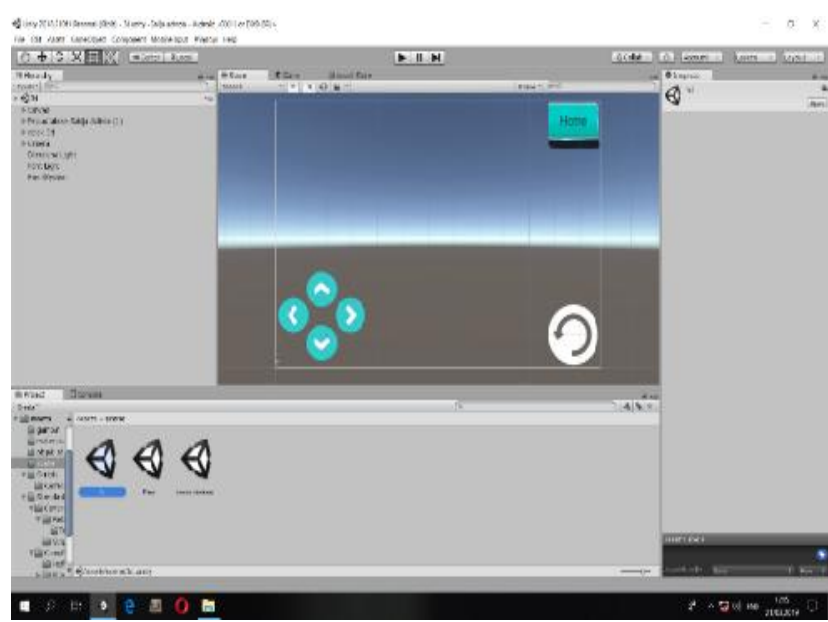

Gambar 6. Tampilan Tombol Fungsi

\section{4). Finishing}

Finishing pada tahap ini bertujuan untuk menyatukan material gambar, suara dan objek lainnya yang telah dibuat menjadi kesatuan aplikasi yang utuh. Player setting digunakan untuk mengatur hasil yang akan di ekstrak ke dalam APK seperti gambar di bawah ini

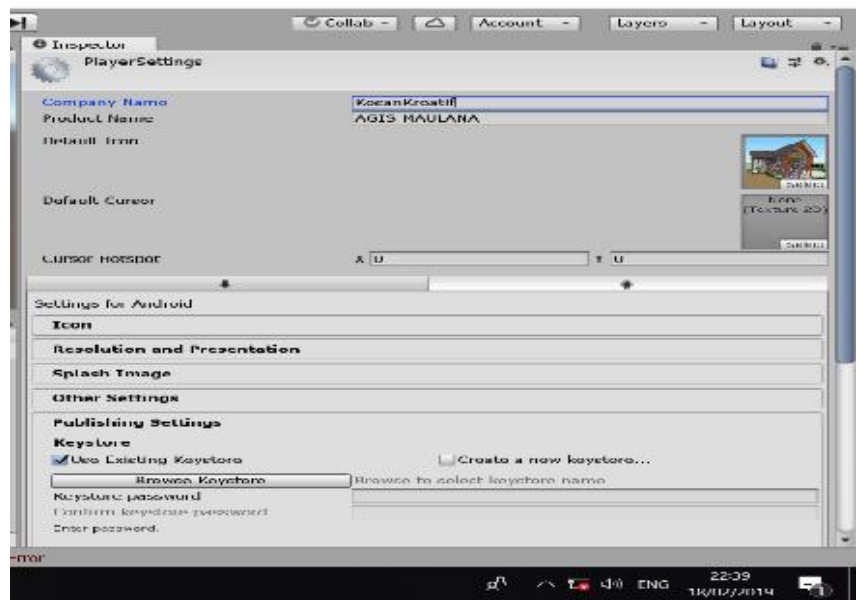

Gambar 7. Player Setting

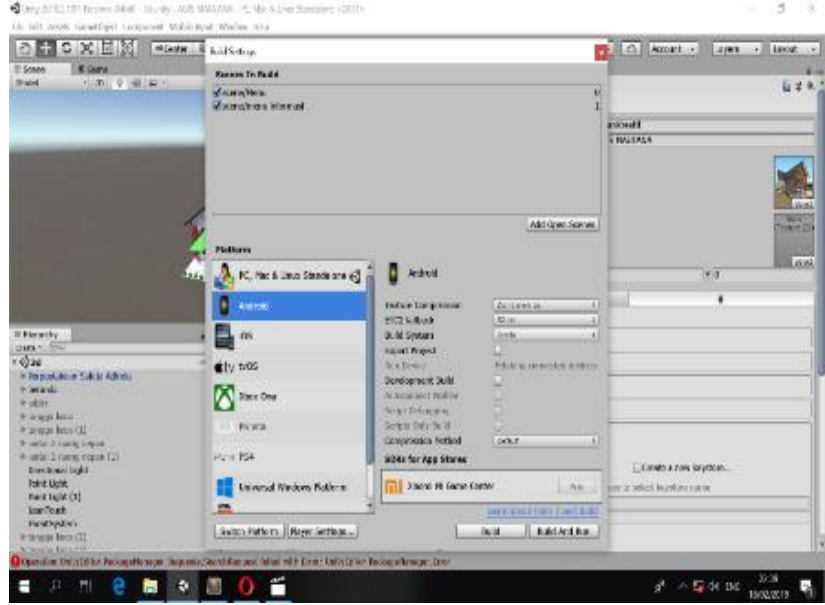

Gambar 8. Tampilan Build Setting

\section{Deskripsi Hasil}

Hasil aplikasi yang telah dibuat dengan software Unity 3D ini akan dijelaskan dalam bentuk Photoboard sebagai berikut :

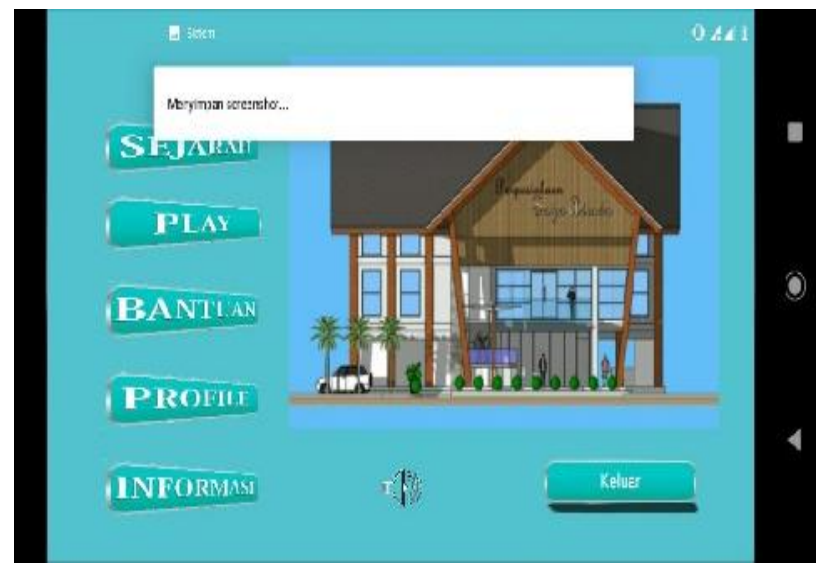

Gambar 9. Tampilan Menu Utama

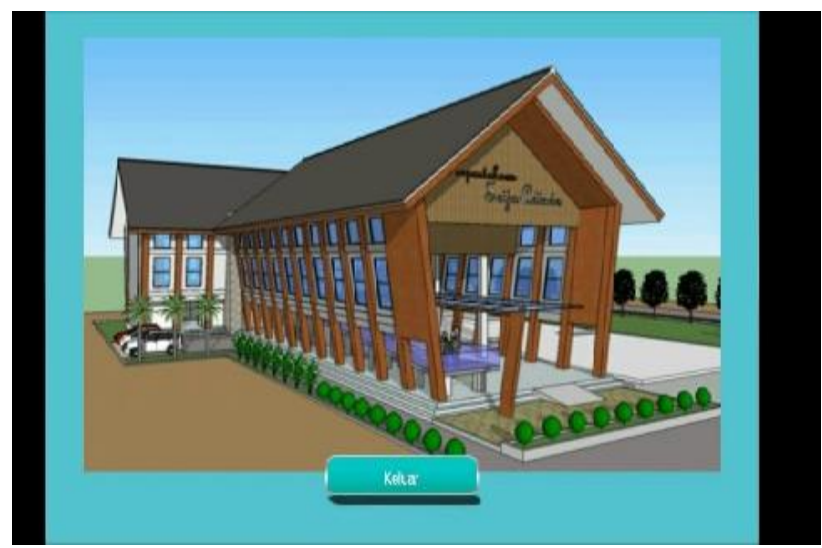


Gambar 10. Tampilan Gedung

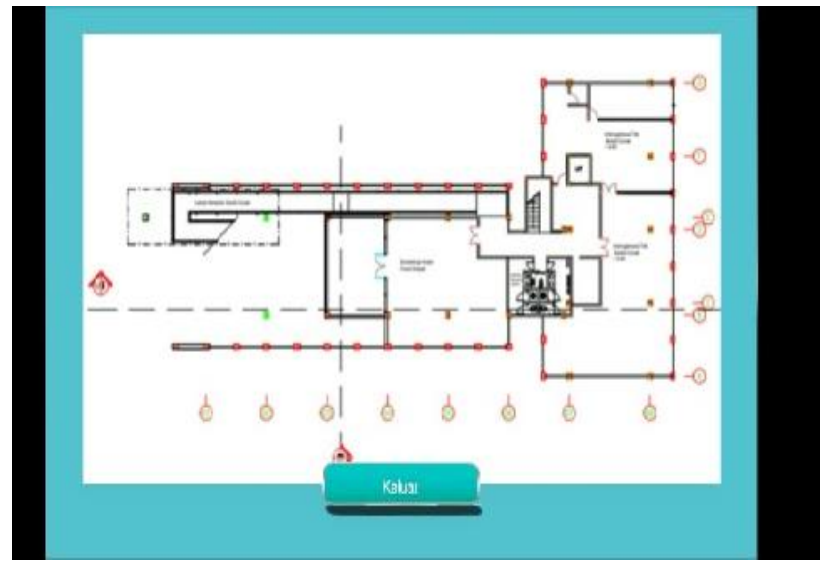

Gambar 11. Tampilan Menu Lantai 1

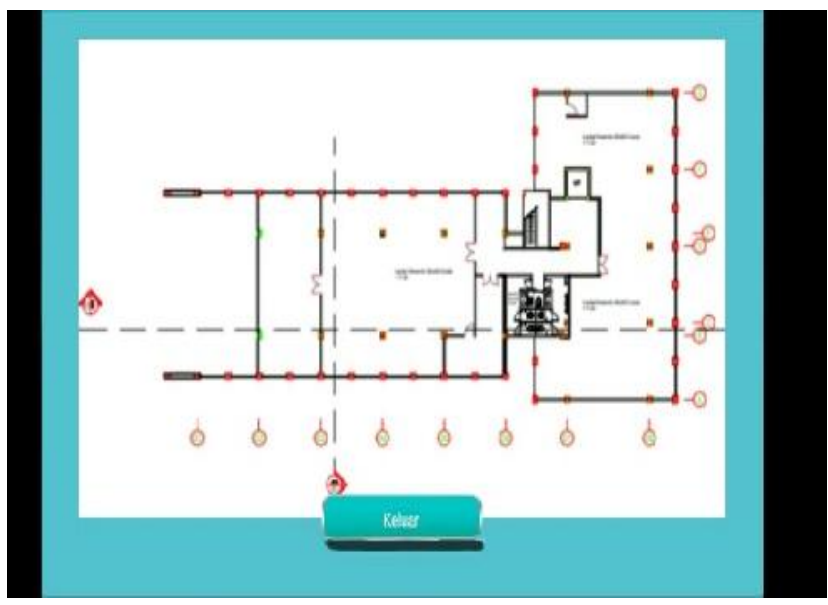

Gambar 12. Tampilan Menu Lantai 2

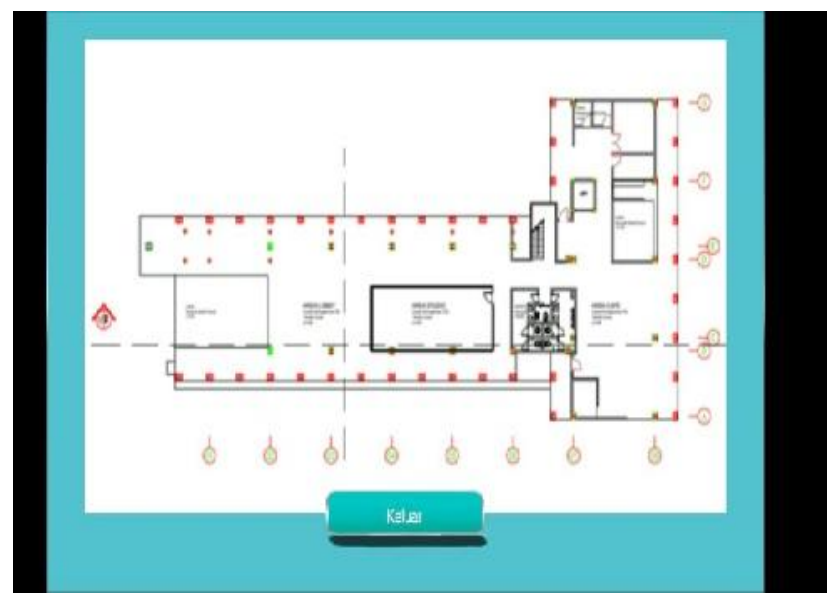

Gambar 13. Tampilan Menu Lantai 3

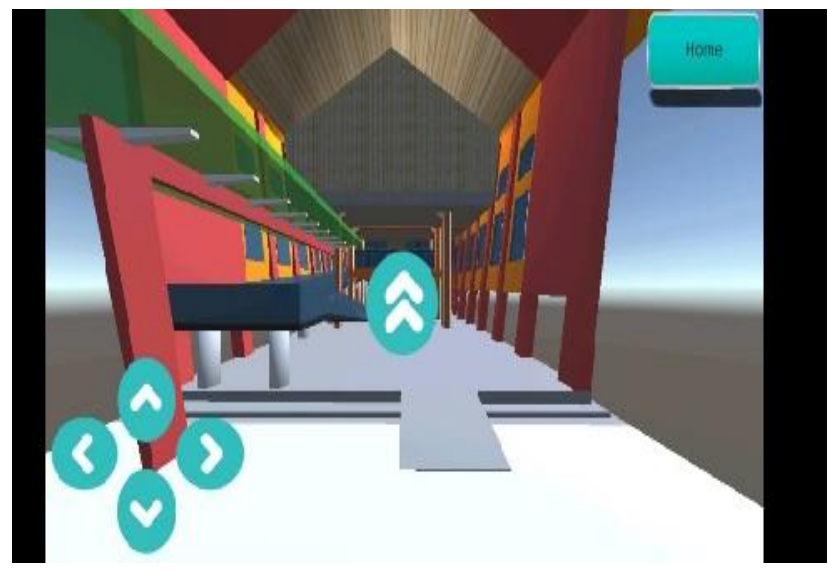

Gambar 14. Tampilan Menu Menu Play

\section{E. Uji Coba (Testing)}

Dilakukan setelah selesai tahap pembuatan (assembly) dengan menjalankan aplikasi atau program untuk melihat apakah ada kesalahan atau tidak. Pengujian dilakukan oleh pembuat atau lingkungan pembuatnya sendiri menggunakan Black Box yang merupakan salah satu metode pengujian perangkat lunak yang berfokus pada sisi fungsionalitas, khususnya pada input dan output aplikasi apakah sudah sesuai dengan apa yang diharapkan atau belum [8]. Pengujian Black Box berusaha menemukan kesalahan dalam kategori sebagai berikut:

a. Fungsi-fungsi yang tidak benar atau hilang

b. Kesalahan Interface

c. Kesalahan Dalam Struktur atau akses

d. Kesalahan Kinerja

e. Inisialisasi dan kesalahan terminasi

\section{F. Distribusi (Distribution)}

Distribusi adalah tahap akhir dari penelitian, yang dimana aplikasi yang telah dibuat didistribusikan ke Google Play agar dapat langsung diunduh dan diinstal serta dapat digunakan secara offline.

Gambar 16. Distribusi Aplikasi Pada Play Store

\section{KESIMPULAN}

Pemanfaatan teknologi Virtual Tour dalam pembuatan aplikasi pengenalan perpustakaan Saija Adinda ini diharapkan dapat memberikan kemudahan pengunjung perpustakaan dalam mengenal tata ruang dan tata letak koleksi buku-buku di perpustakaan Saija Adinda yang telah dibuat semirip mungkin dengan aslinya. Pengunjung perpustakaan dapat mengunduh Aplikasi pengenalan Perpustakaan Saija Adinda 
di Play Store menggunakan smartphone android minimal sistem operasi versi 5.0 lollipop dengan fitur yang sudah disediakan di dalam aplikasi sebagai petunjuk penggunaan aplikasi.

\section{REFERENSI}

[1]. Daud R, Tulenan Virginia dan Najoan. (2016). Virtual Tour Panorama 360 Derajat kampus Universitas Sam Ratulangi Manado. Vol. 8. No (1).1-7. 2016.

[2]. Rosalina, Vidila. Dkk. (2019). Gerakan Donasi Buku Dalam Upaya Membangun Budaya Literasi : Tahap 1, Jurnal Pemberdayaan Masyarakat (JPMI) Volume 1 Nomor 2. 2019.

[3]. Fitri Orina mega. (2016). Rancang Bangun Aplikasi Virtual Tour Monumen Mandala Berbasis Android. Vol. 1. No. (1). 1179-254. 2016.

[4]. Kusmiati herlinda dan Oktafian tri d.. (2018). Rekayasa Perangkat Lunak Virtual Tour Jakabaring Sport City (JSC). Vol. 4. No (2). 1-7. 2018.

[5]. Munir. (2013). Multimedia Konsep \& Aplikasi Dalam Pendidikan. Bandung : Alfabeta,

[6]. Safaat, Nazruddin. Android Pemrograman Aplikasi Mobile Smartphone dan Tablet PC Berbasis Android. (2015). Bandung: Informatika Bandung.

[7]. Seno. (2014). Mudah Membuat Game 3 Dimensi Menggunakan Unity $3 D$.

[8]. Iskandaria, (2018). Contoh Pengijian Black Box. https://ksfegue.com. Diakses tanggal 3 Mei 2018. 